\title{
28 Research Square \\ HIV/AIDS research in Africa and the Middle East: \\ participation and equity in North-South collaborations and relationships.
}

Gregorio González-Alcaide ( $\square$ gregorio.gonzalez@uv.es )

Universitat de Valencia https://orcid.org/0000-0003-3853-5222

Marouane Menchi-Elanzi

Hospital General Universitari d'Alacant

Edy Nacarapa

Carmelo Hospital of Chókwè

José-Manuel Ramos-Rincón

Hospital General Universitari d'Alacant

\section{Research}

Keywords: Scientific research, Human immunodeficiency virus infection, Acquired immune deficiency syndrome, African countries, Bibliometrics, International collaboration, Leadership

Posted Date: December 18th, 2019

DOI: https://doi.org/10.21203/rs.2.19193/v1

License: @ (1) This work is licensed under a Creative Commons Attribution 4.0 International License. Read Full License

Version of Record: A version of this preprint was published at Globalization and Health on September 17th, 2020. See the published version at https://doi.org/10.1186/s12992-020-00609-9. 


\section{Abstract}

Background: HIV/AIDS has attracted considerable research attention since the 1980s. In the current context of globalization and the predominance of cooperative work, it is crucial to analyze the participation of the countries and regions where the infection is most prevalent, African continent being the hardest hit ( $67.5 \%$ of estimated cases). This study assesses the participation of African countries in publications on the topic, as well as the degree of equity or influence existing in North-South relations.

Methods : We identified all articles and reviews of HIV/AIDS indexed in the Web of Science Core Collection. We analyzed the scientific production, collaboration, and contributions from African and Middle Eastern countries to scientific activity in the region. The concept of leadership was used to determine the equity in research produced through international collaboration.

Results: A total of 68,808 documents published from 2010 to 2017 were analyzed. Researchers from North America and Europe participated in $82.14 \%$ of the global scientific production on HIV/AIDS, compared to just $21.61 \%$ from Africa and the Middle East. Furthermore, the research that did come out of these regions was concentrated in a small number of countries, led by South Africa ( $41 \%$ of the documents). Other features associated with HIV/AIDS research from Africa include the importance of international collaboration from the USA, the UK, and other European countries ( $75 \%-93 \%$ of the documents) and the limited leadership that is evident (30\% to $36 \%$ of the documents). Finally, the research to which African countries contributed had a notably different disciplinary orientation, with a predominance of research on public health, epidemiology, and drug therapy.

Conclusions: It is essential to foster more balance in research output, avoid the concentration of resources that reproduces the global North-South model on the African continent, and focus the research agenda on local priorities. To accomplish this, the global North should strengthen the transfer of research skills and seek equity in cooperative ties, favoring the empowerment of African countries. These efforts should be concentrated in countries with low scientific activity and high incidence and prevalence of the disease. It is also essential to foster intraregional collaborations between African countries.

\section{Background}

HIV infection and its clinical manifestation, AIDS, are considered a pre-eminent challenge for global public health [1], affecting populations worldwide since the 1980s. Despite the progress made in prevention and treatment programs, the disease is still pandemic, with the African continent being the hardest hit [2]. An estimated 37.9 million people were living with HIV in 2018, of whom 20.6 million lived in Eastern and Southern Africa, 5 million in Western and Central Africa, and 240,000 in the Middle East and North Africa. The same year saw about 770,000 deaths from this disease and 1.7 million new infections, $61 \%$ of which occurred in sub-Saharan Africa. Over half of the new cases in Eastern and Southern Africa were concentrated in Mozambique, South Africa, and Tanzania, while $71 \%$ of new infections in Western and Central Africa were in Cameroon, the Côte d'Ivoire, and Nigeria. In the Middle East and North Africa, two-thirds of new cases were registered in Egypt, Iran and Sudan [3]. In response to this challenge, researchers worldwide have worked to produce evidence on HIV/AIDS across a wide range of biomedical disciplines, including epidemiology, virology, immunology, and pharmacology, as well as in non-biomedical fields such as social sciences and the humanities. This body of work has situated HIV/AIDS among the most studied infectious diseases today [4]. 
Bibliometrics is a method that enables the quantitative and qualitative assessment of scientific research in any area of knowledge, at an individual, institutional, or national level [5]. In that sense, ample literature has been published on bibliometric analyses of HIV/AIDS research since the 1980s [6, 7], including some papers that focus specifically on the regions most affected by the virus and the infection, like Central Africa [8]; sub-Saharan Africa [9]; or on countries like Kenya, Uganda, Nigeria, or Lesotho $[10,11,12]$. However, many of these papers were published more than a decade ago and investigated the scientific production in the geographical areas analyzed. In the current context of globalization and predominance of cooperative work, Africans are under-represented in terms of authorship in collaborative research publications. This situation has led some investigators to call for studies that quantify authorship equity [13] and explore North-South relationships in research collaboration [8].

The overarching objective of the present study is to provide an up-to-date vision of participation from Africa and the Middle East in the literature on HIV/AIDS published in high-visibility journals, and of the role played by African countries in publications produced in international collaboration. Our specific research questions were: (1) What was the contribution from Africa and the Middle East, both overall and by country, to the global scientific research output on HIV/AIDS? (2) Is North-South participation balanced in papers signed in international collaboration? and (3) Are there differences in the subject-area orientation between publications produced with or without participation from African and Middle Eastern authors on HIV/AIDS research?

\section{Methods}

The methodological process was as follows.

\subsection{Identification of global scientific research production on HIV/AIDS}

To identify the scientific literature on HIV/AIDs, we used the Medical Subject Headings (MeSH) thesaurus of the National Library of Medicine, selecting all of the descriptors related to HIV, human immunodeficiency related to HIV infection, and the development of vaccines for preventing or clinically treating the immunodeficiency. The final MeSH (plus their variants and synonyms) were: HIV, HIV Infections, Acquired Immunodeficiency Syndrome, and AIDS Vaccines.

Although the MeSH thesaurus is linked to the MEDLINE database, which is freely available through the PubMed platform, we performed a second search of the documents identified in MEDLINE and which were also indexed in the Web of Science Core Collection (WoS-CC) databases. Although this database does not cover all of the documents indexed in MEDLINE/PubMed, it does include all of the institutional affiliations (which MEDLINE started listing only in 2014), making it an ideal source for characterizing scientific production by country and the collaboration from Africa and the Middle East in HIV/AIDS research during the study period.

The collection of journals in the WoS-CC, moreover, represents the information sources with the highest visibility at an international level. Thus, using that source to calculate our bibliometric study indicators allows a vision of the development of the most relevant and impactful research worldwide.

\subsection{Definition of the document sample analyzed}

Our literature search yielded 93,031 documents on HIV, 256,354 on HIV Infections, 76,359 on Acquired Immunodeficiency Syndrome, and 7528 on AIDS Vaccines. After removing duplicate descriptors, there were 298,718 unique documents. We then restricted the results to those published from 2010 to 2017 ( $n=83,316)$ in order to focus the analysis on the most recent research. We ruled out the inclusion of documents from 2018 to avoid delays related 
to indexation, as at least a year is needed to ensure updated information related to the assignment of MeSH terms. We subsequently identified the documents that were also included in the WoS-CC databases by searching for all of the documents from the initial sample using their PMIDs (the PubMed identifier used as a reference in MEDLINE and included as a bibliographic field in WoS-CC). In total, $89.29 \%(n=74,375)$ of the MEDLINE documents were also in the WoS-CC. This set of papers was further restricted to three document types: articles, reviews, and letters $(n=68,808)$, chosen because they are the most prominent papers for transmitting the results of original research (articles); situating and evaluating the development of research in a highly relevant way for other researchers (reviews); and contributing critical viewpoints, comments, relevant information, and perspectives on published studies (letters). The searches took place in November 2018. Figure 1 presents a flow chart showing the selection process for the sample of documents analyzed in the study.

\subsection{Download of bibliographic information and review of the standardization of data}

Following the bibliographic search and document selection, we downloaded the bibliographic information from the selected records $(n=68,808)$, generating a relational database in Microsoft Access in order to enumerate and individualize the multiple entries contained in certain bibliographic fields. This is the case of institutional affiliations, as a single field collates the data for all co-authors' institutions and countries. Likewise, the subject area field for the journal of publication may also have several assigned topics, and various $\mathrm{MeSH}$ and other text words are assigned to different documents to describe their content.

We also reviewed the standardization and quality of the data. For example, we looked at the years of publication, as the date of some documents' public dissemination on the journal website differed from the definitive date of publication in the journal (the latter was taken as the reference). Likewise, we consolidated all the information on geographic origins from England, Scotland, Wales, and North Ireland-presented individually in the WoS-CC-under the UK.

\subsection{Identification of participation from Africa and the Middle East in HIV/AIDS research}

To analyze the participation from Africa and the Middle East in HIV/AIDS research, we took as a reference the UNAIDS (2018) definitions of geographical regions, assigning each country to its respective region as defined in that source. The regions were: North America, Western and Central Europe, Asia and Pacific, Eastern and Southern Africa, Latin America and the Caribbean, West and Central Africa, the Middle East and North Africa, and Eastern Europe and Central Asia.

\subsection{Indicators obtained and analyses performed}

The indicators and analyses applied in our study are structured in three blocks.

Analysis of the scientific production, research collaboration and leadership, by geographical region

As an introductory step to understanding global HIV/AIDS research, we quantified absolute scientific production by UNAIDS regions, calculating the number of documents signed by researchers from these areas. Moreover, we assessed inter-regional and international collaboration along with research leadership, defined as the degree of participation as the first author of documents signed in collaboration.

Analysis of research production, collaboration and leadership from countries in Africa and the Middle East 
To specifically analyze HIV/AIDS research production from African and Middle Eastern countries, we determined the number of documents signed by researchers from these countries as well as the proportion of total research with their participation. With regard to research collaboration and leadership, the absolute and relative values on international collaboration are complemented by a specific analysis of research leadership in the top 10 most productive countries in Africa. Furthermore, a directed collaboration network was generated, representing the main African countries collaborating in global HIV/AIDS research. The nodes represent countries, and the links represent countries' participation in the first positions of authorship. This visual representation clarifies the position that different countries occupy in the network and the collaborative links that they have established.

\section{Subject areas and research fields in global HIV/AIDS research production}

We analyzed the research subject areas and fields according to the disciplines that contributed most to scientific production on HIV/AIDS, as identified by means of the subject area classification of scientific journals in the WoS-CC as well as the MeSH descriptors and qualifiers assigned to the documents. To compare research orientations, we present data for global research output, for research produced solely by African countries, and research produced through collaborations between African countries and others (Africa+global collaboration). Pearson's correlation coefficient was estimated for these three groupings to determine the affinity between African and global research production.

Finally, a co-occurrence network of MeSH terms was generated to analyze the relationships between them and to identify the specific subject areas or research orientations on HIV/AIDS in Africa and the Middle East.

Pajek and VoSViewer (Version 1.6.8, Center for Science and Technology, Leiden University) software were used to perform all processes (analysis, network generation) and obtain all descriptive indicators.

\section{Results}

\subsection{Scientific production by region and degree of international collaboration}

Scientific production on HIV/AIDS is dominated by North America (which participated in $55.60 \%$ of all documents analyzed) and by Western and Central Europe (35.79\%). Together, these regions participated in $82.13 \%$ of global scientific research production on HIV/AIDS that was indexed in the sources consulted. For their part, the three regions of Africa and the Middle East participated in $21.61 \%$ of the documents, albeit contributions from Eastern and Southern Africa (17.80\%) were much higher than those from Western and Central Africa (3.34\%) and Middle East and North Africa (1.18\%) (table 1). This limited scientific production contrasts with the high percentages of collaboration observed in these regions; in Eastern and Southern Africa, $82.42 \%$ of the documents were signed in collaboration with countries from other regions, and in Western and Central Africa, $78.39 \%$. In contrast, $43.22 \%$ of the documents from North America were produced in inter-regional collaboration, and 47.99\% from Western and Central Europe. Looking only at documents produced with inter-regional collaboration, authors from Africa and the Middle East occupied the first position on just $30 \%$ to $36 \%$ of the papers, compared to $45 \%$ for Western and Central Europe and $54 \%$ for North America (table 1).

\subsection{Scientific production by country and degree of international collaboration}

Research production in Africa and the Middle East is concentrated in South Africa, which participated in $40.94 \%$ of the documents from these regions. At some distance are several other countries from Eastern and Southern Africa:

Uganda (12.97\%), Kenya (10.71\%), Malawi (6.19\%) and Tanzania (6.03\%). Thirteen other countries show values 
ranging from $1.32 \%$ to $4.73 \%$. Nigeria is the most prominent producer in Western and Central Africa, at $4.59 \%$, while Iran leads production in the Middle East and North Africa (2.02\%). Another 45 countries in Africa and the Middle East contributed to less than one per cent of the total research output (table 2). Among the most productive countries (> 100 documents), Iran, Ethiopia, Nigeria, and South Africa present the lowest degree of international collaboration and the highest participation as first authors. Many of these show values of international collaboration that exceed $90 \%$, with participation as first author under $30 \%$. This situation is similar or even more pronounced in most low-producing countries (table 2).

Generally speaking, African research on HIV/AIDS is characterized by its cooperative links, particularly with the USA, UK, and other European countries ( $75 \%$ to $93 \%$ of the collaborations). However, South Africa also stands out for its intraregional ties, and it has become the main reference for research collaboration on HIV/AIDS, both in Eastern and Southern Africa and among the top 10 most productive African countries. It has collaborated with 34 different countries, led $41.44 \%$ of the collaborations, and participated in $35.76 \%$ of the papers led by other African countries. Uganda ranks second in terms of collaborative leadership within Africa, albeit with values that are much more modest, having led $14.06 \%$ of its collaborative research and participated in $11.11 \%$ of papers led by other African countries. The rest of the countries contribute less than $10 \%$ to the total collaborative links established. Except for South Africa, Uganda, and a few other countries like Zimbabwe, the collaborative links between different countries in Africa are few and far between, constituting weak and sporadic ties (table 3).

Figure 2 shows a graphic representation of the collaboration network. The USA is in the center as the main reference for international collaboration on scientific output on HIV/AIDS, while the UK, Canada, and other European countries like France, Switzerland, the Netherlands, and Belgium also occupy prominent locations. South Africa is the main African reference for HIV/AIDS research, reflecting not only its collaborations with the USA, Canada and the European countries but also its prominent role in intraregional collaborations.

\subsection{Subject areas addressed in research on HIV/AIDS in Africa and the Middle East}

The correlation analysis on scientific HIV/AIDS output, produced by all countries worldwide, by African countries alone, and through Africa+global collaborations, shows differences in disciplinary orientations and research topics. In terms of disciplines involved, the lowest degree of correlation pertains to global research versus solely African research ( $k=0.73$; table 4). There is also certain discordance between solely African research and Africa $+g l o b a l$ collaborations $(k=0.79)$. In contrast, there is great affinity between global research output and output from Africa+global collaborations ( $k=0.97)$. Of note, HIV/AIDS research from Africa alone was dominated by papers in the field of "Public, Environmental \& Occupational Health," while the disciplines of "Infectious Diseases" and "Immunology" occupy the first rankings both globally and in African+global collaborations. The disciplines of "Medicine, General \& Internal" and "Health Policy \& Services" were also of great relevance in the research from African countries alone (table 4).

Our comparison of the MeSH qualifiers revealed similar disparities (table 5). The lowest degrees of correlation were between global versus solely African research output $(\mathrm{k}=0.68)$ and between global versus Africa+global collaborations $(k=0.69)$. However, there was a high degree of correlation between solely African research and Africa+global collaborations $(k=0.97)$. With regard to the most prominent MeSH qualifiers, epidemiological studies occupy the top spot in both global and solely African research. However, "Drug therapy" and "Therapeutic use" are more popular orientations in solely African research than "Inmmunology," “Genetics," and "Metabolism” (table 5).

Finally, with regard to MeSH descriptors, research from Africa and the Middle East reflects the high prioritization of terms related to prevalence and treatment approaches (table 6). Furthermore, global scientific production on HIV/AIDS 
suggests gender parity in terms of the research focus (both the "Male" and "Female" terms were assigned to 55\% of the documents). However, for research produced by solely African countries, the "Female" term is present in $73.38 \%$ of the documents, and for research produced by Africa+global collaborations, this MeSH appeared in $76.71 \%$ of the documents.

Figure 3 presents a visualization of the main MeSH terms used to represent Africa and Middle East HIV/AIDS research topics and the links between them. Overall, studies that analyze anti-HIV agents, prevalence, and risk factors constitute the main subject areas that articulate the research. Incidence and its relation to sexual behaviors and health education (knowledge, prevention, acceptance of treatment for the disease) is also an important topic, as is research on pregnancy, maternal health, and prenatal care. Other relevant areas focus on co-infection (with tuberculosis, hepatitis $B$, hepatitis $C$, meningitis), resistance to anti-viral agents, and the use of certain medicines to treat the infection (lamivudine, tenofovir etc.).

\section{Discussion}

\subsection{Growth, visibility, and concentration of scientific production}

Our analysis shows that scientific production on HIV/AIDS is still dominated by North America and Western and Central Europe, which together participated in $82 \%$ of the documents analyzed, although just $6 \%$ of people with HIV live in these regions. In contrast, countries in Africa and the Middle East participated in less than a quarter of the research papers on HIV/AIDS published between 2010 and 2017 (22\%), although two-thirds of all people who are infected with the virus live there. Nevertheless, in relation to previous studies analyzing HIV/AIDS research produced by African countries, our results indicate two highly relevant trends: (a) the notable growth in scientific production on HIV/AIDS in this region and (b) the elevated participation in scientific publications with greater visibility and international impact. In absolute terms, the number of documents we identified are double those reported by MacíasChapula \& Mijangos-Nolasco [8], based on their analysis of HIV/AIDS literature from sub-Saharan Africa included in the National Library of Medicine from 1980 to 2000, and by Uthman [9] analyzing scientific production on HIV/AIDS from sub-Saharan Africa and indexed in PubMed from 1981 to 2009.

At a country level, the advances made in research are even more significant. In their study on HIV/AIDS literature included in the National Library of Medicine, Onyancha \& Ocholla [10] reported negligible contributions from Uganda and Kenya in the form of journal articles published from 1989 to 1998 ( $n=11$ and $n=16$, respectively). Our results show that these two countries have now become the second and third most productive on the continent, with a high number of contributions to journals indexed in the WoS-CC ( $n=1921$ documents from Uganda and $n=1586$ in Kenya). Uthman [11] studied HIV/AIDS research production from Nigeria between 1987 and 2006, identifying 254 articles in the WoS databases. Our findings, of 679 documents, nearly triple that number, even though the study period is substantially shorter. In South Africa, the production we identified from 2010 to $2017(n=6063)$ is close to that reported by Uthman [9] for the entire period from 1981 to $2009(n=8361)$.

Our results also show a trend toward greater research concentration, with an increase in the relative weight of highproducing countries (particularly South Africa, Uganda, and Kenya), which stand out as the main references for African scientific production on HIV/AIDS. Indeed, these countries now account for over half of all publications from Africa, and their relative contributions are trending upward. Thus, while Uthman [9] reported that South Africa participated in $34 \%$ of the HIV/AIDS research produced by sub-Saharan Africa, in our results this figure stands at $43 \%$. Similarly, the relative weight of Uganda and Kenya (the second and third most productive countries) has risen from $8 \%$ and $7 \%$ of the total contributions, respectively, to $14 \%$ and $11 \%$. Similar observations have been made in other 
research fields [14] and particularly in the biomedical area $[15,16]$, demonstrating that economic development and investments in research constitute key factors explaining the rise in scientific productivity [17].

The trend toward a greater concentration of research production in a few countries indicates the need to develop policies that facilitate a greater integration of lower-producing and less-developed countries in research activities. The literature describes some measures to stimulate research in these countries that go beyond economic investments, including training and retaining experienced researchers and fostering long-term partnerships based on equitable collaborative research ties. These strategies can enable researchers from these countries to acquire the methodological skills they need and can favor their leadership in spearheading or directing the research [13].

More specifically to the field of HIV/AIDS, Uthman [9] analyzed the factors associated with scientific productivity on HIV/AIDS in sub-Saharan Africa. His results showed that the number of people living with HIV and the number of indexed journals published in the country were predictive of an increase in publications. Other relevant factors include national scientific policies related to countries' research agendas for this area, plus the adequate integration and participation in the system for publication and dissemination of scientific knowledge. These variables are more closely associated with scientific productivity on HIV/AIDS than others like the number of higher institutions or the number of physicians. The fact that South Africa is the country with the highest number of HIV-positive people and that this subject area has become a priority on the national research agenda [18] is clearly related to the country's high research productivity in the field. Its economic growth has complemented this boost; together with other BRICS countries, especially China and Brazil, South Africa has laid the groundwork for development by strengthening its educational, healthcare, and social systems $[19,20]$. Increased investments in research go hand in hand with this strategy, including through establishing collaborative links with the most advanced economies at a scientific level [21, 22]. However, as Adams et al. [23] signaled in their study, a myriad of factors affect scientific productivity and collaboration in African countries apart from structural factors like the level of economic growth or population size. For example, countries in the Commonwealth sphere, mostly situated in Eastern and Southern Africa and using English as a second language, generally present a higher level of scientific production and collaborative research than other African countries, like those in the Francophone community [16]. Our results are consistent with this trend: 10 of the 12 most productive countries are linked with the Commonwealth.

Although some countries like Nigeria or Ethiopia have made important research efforts, with corresponding increases in their scientific productivity, different studies have highlighted the need for increasing ties with neighboring countries. This would enable a more fluid exchange of knowledge and experience and foster research in key areas like detection and treatment $[11,24]$.

\subsection{High degree of international collaboration, low level of leadership}

The two main bibliometric features we observed to be associated with HIV/AIDS research activity in Africa were: (a) a high degree of international collaboration with countries from other geographical regions, dominated by the USA and Europe ( $81 \%$ of the documents) and (b) a low level of research leadership, as seen through the low participation of African investigators as the first authors of documents produced in collaboration ( $20 \%$ to $38 \%$ among the top 10 most productive countries).

These two features may reflect a certain scientific dependence and subordination among African countries in relation to more developed countries. Moreover, the same situation has been observed in other biomedical research fields that are of special importance to the global South, like tropical diseases, infectious diseases, and pediatrics $[22,25,26]$. More specifically, Kelaher et al. [27] analyzed randomized controlled trials in the fields of HIV/AIDS, malaria, and tuberculosis that were undertaken in low- and middle-income countries (LMICs) from 1990 to 2013, identifying three 
relevant features associated with research leadership. First, there was a much higher proportion of first authors from LMICs in studies funded by LMICs (90\%) than in studies funded by the USA (32\%). Second, participation as first authors from LMICs was sensibly lower in the field of HIV/AIDS (33\%) than for other diseases like malaria (67\%). Finally, among first authors from all LMICs worldwide, those from Africa signed fewer papers than those from other regions like Latin America or Asia.

The literature describes different barriers that hinder researchers in LMICs from assuming leadership roles. Some of these are related to the scant development of scientific systems. Without an established institutional framework, stable research groups cannot be created or sustained; researchers cannot access the technical and financial support they need to submit research tenders; and coordination and monitoring of research priorities in relation to local research agendas is inadequate $[13,28,29,30]$. Other barriers have to do with deficits in methodological skills (like research design and statistical interpretation) or language (composition of articles or fluency in English). All of these factors can affect researchers' capacity to lead studies and authorship [31, 32, 33].

At the same time, there are structural factors related to the hub-and-spoke model that favor the increased recognition and success of countries conducting mainstream research. Economic and human resources are concentrated in North America and Europe, and these regions also establish priority research topics. Editorial bias and the Matthew effect of accumulated advantage cement the structural forces perpetuating the under-representation of researchers from the global South from assuming positions of leadership in scientific publications [26, 31].

The two countries constituting the axis of the collaborative research network on HIV/AIDS are the USA and South Africa. The former stands out for the high number of collaborative links it has established, with its researchers coauthoring papers with most African and Middle Eastern countries ( 52 countries). In total, 7693 collaborative ties (coauthored papers) were established in the study period, $70 \%$ of which were led by researchers in American institutions. Other bibliometric studies have also described the relevance of the USA in collaborative HIV/AIDS research output in Africa [11], Latin America and the Caribbean [34], and Asia [35]. Our own group have highlighted this role in other biomedical research fields [36].

For its part, South Africa is clearly the country of reference for HIV/AIDS research activity on the African continent, with a quantitative weight that is well above that observed in other biomedical areas in which it also exercises leadership. Nachega et al. [16] assessed the participation of African countries in publications on epidemiology and public health in the WoS databases, reporting that South Africa was represented in $22 \%$ of the documents, Kenya in $10 \%$, and Nigeria in $9 \%$. In our study, $41 \%$ of the documents on HIV/AIDS were signed by researchers in South Africa. This country, along with Ethiopia, is also notable for its leadership, figuring in the affiliations of $38 \%$ of the first authors. A similar phenomenon has also been observed in other fields of the health sciences, such as infectious diseases $[15,37]$.

In addition to maintaining important collaborative ties with the USA and different European countries [38, 39], South Africa has also emerged as a hub for intraregional collaborations within Africa. It has established links with 35 countries-far more than other African countries. Indeed, it is the main collaborator for all the other African countries in the top 10 for HIV/AIDS research productivity, even though these collaborations represent just $12 \%$ of the total collaborations in which South Africa participates. In that sense, some papers have called for BRICS countries, including South Africa, to increase their efforts to tackle the challenges primarily affecting the developing world [19]. In the case of South Africa, this could be done by promoting intraregional collaborations in sub-Saharan Africa, as research undertaken at a local level has the most potential to produce benefits, both for population health and socioeconomic development [20, 40]. Hernandez-Villafuerte, Li \& Hofman [41] analyzed collaborations among sub- 
Saharan countries conducting economic evaluations of healthcare interventions, reporting results consistent with ours: researchers in this region tend to collaborate more with Europeans and North Americans than with each other.

\subsection{Research interests in public health, epidemiology, and treatment approaches}

HIV/AIDS research produced by solely African countries differed from global research in terms of disciplinary and subject area orientations, with a greater focus on public health, epidemiology, and treatment. This finding indicates the need to consider regional, national, and local specificities and interests when determining research priorities. In fact, numerous studies have already signaled the poor alignment between the priorities laid out in African countries' national research agendas and the research topics that are actually financed $[12,16,42,43,44,45]$.

From a public health perspective, for example, Uthman [11] pointed out the need for further research evidence to inform HIV prevention and control programs. In this field, some countries perform better than others: South Africa is particularly strong in public health research [46], while other African countries and regions, such as French Africa, have made limited contributions [48].

Studies on epidemiology and treatment approaches for HIV/AIDS are very relevant for research produced in Africa, in contrast to what occurs on a global scale, where these orientations have a relatively limited weight. Nachega et al. [16] pointed out that research on HIV/AIDS, tuberculosis, and malaria have become the main research topics addressed in epidemiological and public health publications in African countries. However, these authors argued for moving epidemiology and public health research beyond the limited sphere of communicable disease control in order to address the regional impact of non-communicable diseases, for example in maternal and child health. This is especially relevant in the case of sub-Saharan Africa, where epidemiologists are overwhelmingly deployed to control infectious diseases, especially HIV/AIDS, tuberculosis, and malaria. The study also calls for strengthening regional expertise in epidemiology in order to shed light on the underlying causes of ill health, rather than to merely control infections and outbreaks [16].

In addition to epidemiological studies, African research also reflects an intense interest in drug therapies for HIV/AIDS, illustrating that control of the infection is a priority for research agendas and policies in African countries [12].

More specifically, previous literature on HIV/AIDS research has shown a greater focus on women in studies carried out with the participation of African researchers [10]. Our study confirms this finding: $73 \%$ to $77 \%$ of the documents investigated women, compared to $55 \%$ in the global literature. One possible explanation for this includes the fact that women are more biologically, economically, socially, and culturally vulnerable to infection. Indeed, for every 10 African men who are HIV-positive, there are 12 to 13 infected women; moreover, 55\% of adults who acquire HIV are women, with profound implications for mother-to-child transmission [10]. The different epidemiological patterns of HIV/AIDS transmission in North America and Western and Central Europe must also be taken into account, that motivate a greater interest of research in these regions on sexual transmission between men and intravenous drug users. These epidemiological patterns are less important in Africa [48]. The presence in the MeSH co-occurrence network of the descriptors "pregnancy" and "sexual behavior" are noteworthy, reflecting how African researchers are investigating aspects like maternal-fetal transmission of HIV [49] or knowledge and prevention of sexual risk, and changing the preconceptions that still persist about the social determinants of transmission [43]. The prominence of topics related to preventing mother-to-child transmission stands in contrast to the near absence of topics related to children and young people. These groups are especially sensitive to the physical and psychosocial impacts of HIV and AIDS, indicating the need for increased research on young people who are at risk of or living with HIV [50].

\subsection{Limitations and future lines of research}

Page $10 / 25$ 
Limitations of the present study include the fact that a considerable portion of HIV/AIDS research in African countries is disseminated using document types and media that we did not consider, such as meeting abstracts and journals that are not indexed in the WoS-CC. Moreover, using the MeSH thesaurus from the field of health sciences could have resulted in an underestimation of research spheres related to our subject area, such as research in the social sciences. In that sense, some papers have indicated that stigma and discrimination still constitute the main barriers to controlling HIV/AIDS [51].

Our study focused on obtaining macro indicators on scientific collaboration and output by regions and countries. Future lines of research could conduct meso- or microlevel analyses, for example focusing on the participation of institutions or authors in African HIV/AIDS research or on the impact of the publications.

\section{Conclusions}

The main conclusions of our study are as follows.

1. Our results reflect significant progress in African-produced HIV/AIDS research, at both a quantitative level (with notable increases in the number of publications) and qualitative level (through participation in journals indexed in a bibliographic database that brings together the most high-impact and high-visibility international publications). Despite these advances, however, scientific output is still concentrated in a small number of countries, chief among them South Africa, while other countries in Africa and the Middle East make only negligible contributions, despite the high burden of HIV infections.

2. The participation of African countries conducting HIV/AIDS research is characterized by a dependence on and subordination to the USA and European countries. Collaborations between these regions reflect limited leadership by African countries, as measured by the participation of African researchers as the first authors of published studies.

3. HIV/AIDS research conducted with participation from African countries shows appreciably different disciplinary and subject-area interests than global HIV/AIDS research, with a stronger focus on public health, epidemiology, and drug treatments.

It is essential to promote balanced North-South research that properly addresses the most acute needs and gaps in the places where HIV/AIDS has the largest impact. To achieve this balance, it is necessary to transfer research skills to African partners, promote equitable collaborative ties, and empower African countries, especially those with less scientific activity and more disease prevalence. Intraregional collaborations among African countries can also help to avoid the further concentration of research capacity, reproducing the global North-South model on the African continent.

\section{Declarations}

\section{Ethics approval and consent to participate}

Not applicable

\section{Consent for publication}

Not applicable

\section{Availability of data and materials}


The datasets generated and/or analysed during the current study are available in the Harvard Dataverse repository, https://doi.org/10.7910/DVN/RJMAY5.

\section{Competing interests}

The authors declare that they have no competing interests.

\section{Funding}

The authors received no specific funding for this work.

\section{Authors' contributions}

GGA: study conception, data collection, data analysis, manuscript writing and final manuscript approval; MME: study conception, data collection, data analysis, manuscript writing and final manuscript approval; NE: data analysis, manuscript writing and final manuscript approval; JMRR: study conception, manuscript writing and final manuscript approval.

\section{Acknowledgements}

We gratefully acknowledge the assistance of Meggan Harris in translating our manuscript from Spanish.

\section{References}

[1] GBD 2015 HIV Collaborators. Estimates of global, regional, and national incidence, prevalence, and mortality of HIV, 1980-2015: the global burden of disease study 2015. Lancet HIV. 2016;3:e361-87.

[2] Galvani AP, Pandey A, Fitzpatrick MC, Medlock J, Gray GE. Defining control of HIV epidemics. Lancet HIV. 2018;5:e667-70.

[3] UNAIDS Data 2018. https://www.unaids.org/sites/default/files/media_asset/unaids-data-2018_en.pdf. Accessed 15 Dec 2019.

[4] Fajardo-Ortiz D, López-Cervantes M, Duran L, Dumontier M, Lara M, Ochoa $\mathrm{H}$, et al. The emergence and evolution of the research fronts in HIV/AIDS research. PLoS One. 2017;12:e0178293.

[5] González-Alcaide G, Salinas A, Ramos JM. Scientometrics analysis of research activity and collaboration patterns in Chagas cardiomyopathy. PLoS Negl Trop Dis. 2018;12:e0006602.

[6] Macias-Chapula CA, Rodeo-Castro IP, Narvaez-Berthelemot N. Bibliometric analysis of AIDS literature in Latin America and the Caribbean. Scientometrics. 1998;41:41-9.

[7] Sengupta IN, Kumari L. Bibliometric analysis of AIDS literature. Scientometrics. 1991;20:297-315.

[8] Macías-Chapula CA, Mijangos-Nolasco A. Bibliometric analysis of AIDS literature in Central Africa. Scientometrics. 2002;54:309-17.

[9] Uthman OA. Pattern and determinants of HIV research productivity in sub-Saharan Africa: bibliometric analysis of 1981 to 2009 Pubmed papers. BMC Infect Dis. 2010;10:47. 
[10] Onyancha OB, Ocholla DN. A comparative study if the literature on HIV/AIDS in Kenya and Uganda: a bibliometric study. Libr Inf Sci. 2004;26:434-47.

[11] Uthman OA. HIV/AIDS in Nigeria: a bibliometric analysis. BMC Infect Dis. 2008;8:19.

[12] Mugomeri E, Bekele BS, Mafaesa M, Maibvise C, Tarirai C, Aiyuk SE. A 30-year bibliometric analysis of research coverage on HIV and AIDS in Lesotho. Health Res Policy Syst. 2017;15:21.

[13] Chu KM, Jayaraman S, Kyamanywa P, Ntakiyiruta G. Building research capacity in Africa: equity and global health collaborations. PLoS Med. 2014;11:e1001612.

[14] Tijssen R. Africa's contribution to the worldwide research literature: new analytical perspectives, trends, and performance indicators. Scientometrics. 2007;71:303-27.

[15] Uthman OA, Uthman MB. Geography of Africa biomedical publications: an analysis of 1996-2005 PubMed papers. Int J Health Geogr. 2007;6:46.

[16] Nachega JB, Uthman OA, Ho Y-S, Lo M, Anude C, Kayembe P. Current status and future prospects of epidemiology and public health training and research in the WHO African region. Int J Epidemiol. 2012;41:1829-46.

[17] Rahman M, Fukui T. Biomedical research productivity: factors across the countries. Int J Technol Assess Health Care. 2003;19:249-52.

[18] Dwyer-Lindgren L, Cork MA, Sligar A, Steuben KM, Wilson KF, Provost NR, et al. Mapping HIV prevalence in subSaharan Africa between 2000 and 2017. Nature. 2019;570:189-93.

[19] Bai J, Li W, Huang YM, Guo Y. Bibliometric study of research and development for neglected diseases in the BRICS. Infect Dis Poverty. 2016;5:89.

[20] Sun J, Boing AC, Silveira MPT, Bertoldi AD, Ziganshina LE, Khaziakhmetova VN, et al. Efforts to secure universal access to HIV/AIDS treatment: a comparison of BRICS countries. J Evid Based Med. 2014;7:2-21.

[21] Bornmann L, Wagner C, Leydesdorff L. BRICS countries and scientific excellence: A bibliometric analysis of most frequently cited papers. J Assoc Inf Sci Technol. 2015;66:1507-13.

[22] González-Alcaide G, Park J, Huamaní C, Ramos JM. Dominance and leadership in research activities: Collaboration between countries of differing human development is reflected through authorship order and designation as corresponding authors in scientific publications. PLoS One. 2017;12:e0182513.

[23] Adams J, Gurney K, Hook D, Leydesdorff L. International collaboration clusters in Africa. Scientometrics. 2014;98:547-56.

[24] Deribew A, Biadgilign S, Deribe K, Dejene T, Tessema GA, Melaku YA, et al. The burden of HIV/AIDS in Ethiopia from 1990 to 2016: Evidence from the global burden of diseases 2016 study. Ethiop J Health Sci. 2019;29:859-68.

[25] Keiser J, Utzinger J. Trends in the core literature on tropical medicine: a bibliometric analysis from 1952-2002. Scientometrics. 2005;62:351-65.

[26] Keiser J, Utzinger J, Tanner M, Singer BH. Representation of authors and editors from countries with different human development indexes in the leading literature on tropical medicine: survey of current evidence. BMJ.

Page $13 / 25$ 
[27] Kelaher M, Ng L, Knight K, Rahadi A. Equity in global health research in the new millennium: trends in firstauthorship for randomized controlled trials among low- and middle-income country researchers 1990-2013. Int J Epidemiol. 2016;45:2174-83.

[28] Feldacker C, Pintye J, Jacob S, Chung MH, Middleton L, lliffe J, et al. Continuing professional development for medical, nursing, and midwifery cadres in Malawi, Tanzania and South Africa: A qualitative evaluation. PLoS One. 2017;12(10):e0186074.

[29] Nchinda TC. Research capacity strengthening in the South. Soc Sci Med. 2002;54:1699-711.

[30] Wight D, Ahikireb J, Kwesigac JC. Consultancy research as a barrier to strengthening social science research capacity in Uganda. Soc Sci Med. 2014;116:32-40.

[31] Langer A, Díaz-Olavarrieta C, Berdichevsky K, Villar J. Why is research from developing countries underrepresented in international health literature, and what can be done about it? Bull World Health Organ. 2004;82:802-3.

[32] Smith E, Hunt M, Master Z. Authorship ethics in global health research partnerships between researchers from low or middle income countries and high income countries. BMC Med Ethics. 2014;15:42.

[33] Yousefi-Nooraie R, Shakiba B, Mortaz-Hejri S. Country development and manuscript selection bias: a review of published studies. BMC Med Res Methodol. 2006;6:37.

[34] Macias-Chapula CA. AIDS in Haiti: a bibliometric analysis. Bull Med Libr Assoc. 2000;88:56-61.

[35] Chen TJ, Chen YC, Hwang SJ, Chou LF. International collaboration of clinical medicine research in Taiwan, 19902004: A bibliometric analysis. J Chin Med Assoc. 2007;70:110-6.

[36] Ramos-Rincón, J.M., Pinargote-Celorio, H., Belinchón-Romero, I. et al. A snapshot of pneumonia research activity and collaboration patterns (2001-2015): a global bibliometric analysis. BMC Med Res Methodol. 2019:19:184.

[37] Badenhorst A, Mansoori P, Chan KY. Assessing global, regional, national and sub-national capacity for public health research: a bibliometric analysis of the Web of Science in 1996-2010. J Glob Health. 2016;6:010504.

[38] Falagas ME, Bliziotis IA, Soteriades ES. Eighteen years of research on AIDS: contribution of and collaborastion between different world regions. AIDS Res Hum Retroviruses. 2006;22:1199-205.

[39] Breugelmans JG, Makanga MM, Cardoso AL, Mathewson SB, Sheridan-Jones BR, Gurney KA, et al. Bibliometric assessment of European and Sub-Saharan African research output on poverty-related and neglected infectious diseases from 2003 to 2011. PLoS Negl Trop Dis. 2015;9:e0003997.

[40] Ettarh R. Patterns of international collaboration in cardiovascular research in sub-Saharan Africa. Cardiovasc J Afr. 2016;27:194-200.

[41] Hernandez-Villafuerte K, Li R, Hofman KJ. Bibliometric trends of health economic evaluation in Sub-Saharan Africa. Global Health. 2016;12:50.

[42] Mayosi BM, Lawn JE, van Niekerk A, Bradshaw D, Abdool Karim SS, Coovadia HM, et al. Health in South Africa: changes and challenges since 2009. Lancet. 2012;380:2029-43. 
[43] Hodes R, Morrell R. Incursions from the epicentre: Southern theory, social science, and the global HIV research domain. Afr J AIDS Res. 2018;17:22-31.

[44] Esser DE, Bench KK. Does global health funding respond to recipients' needs? Comparing public and private donors' allocations in 2005-2007. World Dev. 2011;39:1271-80.

[45] Swingler GH, Pillay V, Pienaar ED, loannidis JP. International collaboration, funding and association with burden of disease in randomized controlled trials in Africa. Bull World Health Organ. 2005;83:511-7.

[46] Wright CY, Dominick F, Kunene Z, Kapwata T, Street RA. Bibliometric trends of South African environmental health articles between 1998 and 2015: Making local research visible and retrievable. S Afr Med J. 2017;107:915-24.

[47] Benie-Bi J, Cambon L, Grimaud O, Kivits J, Alla F. Health needs and public health functions addressed in scientific publications in Francophone sub-Saharan Africa. Public Health. 2013;127:860-6.

[48] Beyrer C, Baral SD, van Griensven F, Goodreau SM, Chariyalertsak S, Wirtz AL, et al. Global epidemiology of HIV infection in men who have sex with men. Lancet. 2012;380:367-77.

[49] Poreau B. Prenatal diagnosis, care and management in Africa: bibliometric analysis. Pan Afr Med J. 2018;29:146.

[50] Tran BX, Nathan KI, Phan HT, Hall BJ, Vu GT, Vu LG, et al. A global bibliometric analysis of services for children affected by HIV/Acquired Immune Deficiency Syndrome: Implications for impact mitigation programs

(GAPRESEARCH). AIDS Rev. 2019;21.

[51] Sweileh WM. Bibliometric analysis of literature in AIDS-related stigma and discrimination. Transl Behav Med. 2019;9:617-28.

\section{Tables}

Table 1. Scientific production on HIV/AIDS, by geographical region (2010-2017)

\begin{tabular}{|c|c|c|c|c|c|c|}
\hline \multirow[t]{2}{*}{ Geographical area } & \multicolumn{2}{|c|}{$\begin{array}{c}\text { Total } \\
\text { documents }\end{array}$} & \multicolumn{2}{|c|}{$\begin{array}{l}\text { Inter-regional } \\
\text { collaborations }\end{array}$} & \multicolumn{2}{|c|}{$\begin{array}{c}\text { First author in inter-regional } \\
\text { collaboration }\end{array}$} \\
\hline & $\mathbf{N}$ & $\%$ & $\mathbf{N}$ & $\%$ & $\mathbf{N}$ & $\%$ \\
\hline North America & 38,259 & 55.60 & 16,535 & 43.22 & 8914 & 53.91 \\
\hline Western and Central Europe & 24,625 & 35.79 & 11,817 & 47.99 & 5342 & 45.21 \\
\hline Asia and Pacific & 12,473 & 18.13 & 6019 & 48.26 & 2760 & 45.85 \\
\hline Eastern and Southern Africa & 12,249 & 17.80 & 10,096 & 82.42 & 3633 & 35.98 \\
\hline $\begin{array}{l}\text { Latin America and the } \\
\text { Caribbean }\end{array}$ & 4358 & 6.33 & 2073 & 47.57 & 724 & 34.93 \\
\hline West and Central Africa & 2300 & 3.34 & 1803 & 78.39 & 546 & 30.28 \\
\hline Middle East and North Africa & 814 & 1.18 & 467 & 57.37 & 156 & 33.40 \\
\hline $\begin{array}{l}\text { Eastern Europe and Central } \\
\text { Asia }\end{array}$ & 632 & 0.92 & 496 & 78.48 & 104 & 20.97 \\
\hline Total & 68,808 & 100 & 22,082 & 32.09 & $N / A$ & $N / A$ \\
\hline
\end{tabular}

Table 2. Africa and Middle East scientific production on HIV/AIDS, by country (2010-2017) 


\begin{tabular}{|c|c|c|c|c|c|c|c|}
\hline \multirow[t]{2}{*}{ Country } & \multirow[t]{2}{*}{$\begin{array}{l}\text { UNAIDS } \\
\text { region* }\end{array}$} & \multicolumn{2}{|c|}{ Total documents } & \multicolumn{2}{|c|}{$\begin{array}{l}\text { International } \\
\text { collaborations }\end{array}$} & \multicolumn{2}{|c|}{$\begin{array}{c}\text { First author in international } \\
\text { collaboration }\end{array}$} \\
\hline & & $\mathbf{N}$ & $\begin{array}{c}\text { \% African } \\
\text { documents }\end{array}$ & $\mathbf{N}$ & $\%$ & $\mathbf{N}$ & $\%$ \\
\hline South Africa & E \& SA & 6063 & 40.94 & 4620 & 76.2 & 1769 & 38.29 \\
\hline Uganda & $\mathrm{E} \& \mathrm{SA}$ & 1921 & 12.97 & 1797 & 93.55 & 550 & 30.61 \\
\hline Kenya & $\mathrm{E} \& \mathrm{SA}$ & 1586 & 10.71 & 1521 & 95.9 & 327 & 21.5 \\
\hline Malawi & $\mathrm{E} \& \mathrm{SA}$ & 916 & 6.19 & 865 & 94.43 & 214 & 24.74 \\
\hline Tanzania & E \& SA & 893 & 6.03 & 832 & 93.17 & 189 & 22.72 \\
\hline Zimbabwe & $\mathrm{E} \& \mathrm{SA}$ & 700 & 4.73 & 672 & 96 & 134 & 19.94 \\
\hline Zambia & E \& SA & 697 & 4.71 & 684 & 98.13 & 140 & 20.47 \\
\hline Nigeria & W \& CA & 679 & 4.59 & 425 & 62.59 & 144 & 33.88 \\
\hline Ethiopia & $\mathrm{E} \& \mathrm{SA}$ & 555 & 3.75 & 332 & 59.82 & 132 & 39.76 \\
\hline Cameroon & W \& CA & 421 & 2.84 & 363 & 86.22 & 111 & 30.58 \\
\hline Botswana & $\mathrm{E} \& \mathrm{SA}$ & 375 & 2.53 & 356 & 94.93 & 77 & 21.63 \\
\hline Mozambique & $E \& S A$ & 303 & 2.05 & 293 & 96.7 & 80 & 27.3 \\
\hline Iran & $\mathrm{ME} \& \mathrm{NA}$ & 299 & 2.02 & 102 & 34.11 & 57 & 55.88 \\
\hline Ghana & $\mathrm{W} \& \mathrm{CA}$ & 270 & 1.82 & 229 & 84.81 & 50 & 21.83 \\
\hline Rwanda & E \& SA & 269 & 1.82 & 264 & 98.14 & 78 & 29.55 \\
\hline Senegal & W \& CA & 231 & 1.56 & 214 & 92.64 & 39 & 18.22 \\
\hline Côte d'Ivoire & $\mathrm{W} \& \mathrm{CA}$ & 225 & 1.52 & 206 & 91.56 & 40 & 19.42 \\
\hline Burkina Faso & $\mathrm{W} \& \mathrm{CA}$ & 196 & 1.32 & 180 & 91.84 & 49 & 27.22 \\
\hline DR Congo & W \& CA & 119 & 0.80 & 106 & 89.08 & 27 & 25.47 \\
\hline Egypt & ME \& NA & 108 & 0.73 & 89 & 82.41 & 7 & 7.87 \\
\hline Saudi Arabia & ME \& NA & 107 & 0.72 & 81 & 75.7 & 23 & 28.4 \\
\hline Namibia & E \& SA & 100 & 0.68 & 95 & 95 & 11 & 11.58 \\
\hline Swaziland & $\mathrm{E} \& \mathrm{SA}$ & 98 & 0.66 & 95 & 96.94 & 10 & 10.53 \\
\hline Qatar & ME \& NA & 89 & 0.60 & 89 & 100 & 38 & 42.7 \\
\hline Benin & W \& CA & 79 & 0.53 & 75 & 94.94 & 6 & 8 \\
\hline Gambia & W \& CA & 78 & 0.53 & 75 & 96.15 & 19 & 25.33 \\
\hline Gabon & $\mathrm{W} \& \mathrm{CA}$ & 76 & 0.51 & 68 & 89.47 & 17 & 25 \\
\hline Guinea Bissau & $\mathrm{W} \& \mathrm{CA}$ & 69 & 0.47 & 69 & 100 & 32 & 46.38 \\
\hline Mali & $\mathrm{W} \& \mathrm{CA}$ & 69 & 0.47 & 65 & 94.2 & 10 & 15.38 \\
\hline Togo & $\mathrm{W} \& \mathrm{CA}$ & 67 & 0.45 & 59 & 88.06 & 14 & 23.73 \\
\hline Lesotho & E \& SA & 58 & 0.39 & 57 & 98.28 & 17 & 29.82 \\
\hline Morocco & ME \& NA & 55 & 0.37 & 26 & 47.27 & 9 & 34.62 \\
\hline Lebanon & ME \& NA & 52 & 0.35 & 42 & 80.77 & 11 & 26.19 \\
\hline U Arab Emirates & ME \& NA & 44 & 0.30 & 39 & 88.64 & 4 & 10.26 \\
\hline Guinea & $\mathrm{W} \& \mathrm{CA}$ & 36 & 0.24 & 31 & 86.11 & 5 & 16.13 \\
\hline $\begin{array}{l}\text { Republic of the } \\
\text { Congo }\end{array}$ & $\mathrm{W} \& \mathrm{CA}$ & 32 & 0.22 & 25 & 78.13 & 3 & 12 \\
\hline Cent Afr Republ & $\mathrm{W} \& \mathrm{CA}$ & 23 & 0.16 & 20 & 86.96 & 4 & 20 \\
\hline Sudan & ME \& NA & 23 & 0.16 & 21 & 91.3 & 5 & 23.81 \\
\hline Tunisia & $\mathrm{ME} \& \mathrm{NA}$ & 23 & 0.16 & 10 & 43.48 & 5 & 50 \\
\hline Angola & $E \& S A$ & 19 & 0.13 & 18 & 94.74 & 3 & 16.67 \\
\hline Kuwait & ME \& NA & 16 & 0.11 & 10 & 62.5 & 2 & 20 \\
\hline Oman & ME \& NA & 16 & 0.11 & 10 & 62.5 & 2 & 20 \\
\hline Madagascar & $\mathrm{E} \& \mathrm{SA}$ & 15 & 0.10 & 13 & 86.67 & 1 & 7.69 \\
\hline Niger & W \& CA & 15 & 0.10 & 15 & 100 & 1 & 6.67 \\
\hline Iraq & $\mathrm{ME} \& \mathrm{NA}$ & 13 & 0.09 & 10 & 76.92 & 0 & 0 \\
\hline Sierra Leone & $\mathrm{W} \& \mathrm{CA}$ & 13 & 0.09 & 13 & 100 & 2 & 15.38 \\
\hline Jordan & ME \& NA & 12 & 0.08 & 9 & 75 & 4 & 44.44 \\
\hline
\end{tabular}




\begin{tabular}{|c|c|c|c|c|c|c|c|}
\hline Liberia & W \& CA & 12 & 0.08 & 12 & 100 & 1 & 8.33 \\
\hline Libya & ME \& NA & 12 & 0.08 & 7 & 58.33 & 3 & 42.86 \\
\hline Burundi & W \& CA & 11 & 0.07 & 11 & 100 & 1 & 9.09 \\
\hline Chad & W \& CA & 9 & 0.06 & 8 & 88.89 & 1 & 12.5 \\
\hline Cape Verde & W \& CA & 5 & 0.03 & 5 & 100 & 2 & 40 \\
\hline Mauritania & W \& CA & 5 & 0.03 & 5 & 100 & 3 & 60 \\
\hline Mauritius & $E \& S A$ & 5 & 0.03 & 5 & 100 & 0 & 0 \\
\hline Algeria & ME \& NA & 4 & 0.03 & 2 & 50 & 1 & 50 \\
\hline Bahrain & ME \& NA & 4 & 0.03 & 3 & 75 & 1 & 33.33 \\
\hline Equat Guinea & W \& CA & 4 & 0.03 & 4 & 100 & 0 & 0 \\
\hline Syria & ME \& NA & 4 & 0.03 & 4 & 100 & 0 & 0 \\
\hline Yemen & ME \& NA & 4 & 0.03 & 4 & 100 & 1 & 25 \\
\hline Djibouti & ME \& NA & 2 & 0.01 & 2 & 100 & 2 & 100 \\
\hline Somalia & ME \& NA & 2 & 0.01 & 2 & 100 & 2 & 100 \\
\hline Palestinian Ter & ME \& NA & 1 & 0.01 & 1 & 100 & 0 & 0 \\
\hline Sao Tome \& Prin & $\mathrm{W} \& \mathrm{CA}$ & 1 & 0.01 & 0 & 0 & 0 & 0 \\
\hline TOTAL & - & 14,808 & 100 & 11,964 & 80.79 & $N / A$ & $N / A$ \\
\hline
\end{tabular}

E \& SA: Eastern and Southern Africa; W \& CA: West and Central Africa; ME \& NA: Middle East and North Africa. N/A: Not applicable.

Table 3. Collaboration and leadership of top 10 African countries in research papers on HIV/AIDS (2010-2017) 


\begin{tabular}{|c|c|c|c|c|c|c|c|}
\hline \multicolumn{2}{|c|}{ Collaborative leadership } & \multicolumn{3}{|c|}{ Collaborations with African countries } & \multicolumn{3}{|c|}{ Collaborations with non-African countries } \\
\hline Country & $\begin{array}{c}\text { Total } \\
\text { collaborations }\end{array}$ & $\begin{array}{c}\mathrm{N} \\
\text { countries }\end{array}$ & $\begin{array}{c}\text { N } \\
\text { collaborations } \\
(\%)\end{array}$ & $\begin{array}{l}\text { Main African } \\
\text { collaborators } \\
\text { (n } \\
\text { collaborations) }\end{array}$ & $\begin{array}{c}\mathrm{N} \\
\text { countries }\end{array}$ & $\begin{array}{c}\text { N } \\
\text { collaborations } \\
(\%)\end{array}$ & $\begin{array}{l}\text { Main non- } \\
\text { African } \\
\text { collaborators } \\
\text { (n } \\
\text { collaborations) }\end{array}$ \\
\hline $\begin{array}{l}\text { South } \\
\text { Africa }\end{array}$ & 2810 & 34 & $392(13.95)$ & $\begin{array}{l}\text { Zimbabwe } \\
(\mathrm{n}=44) ; \\
\text { Uganda } \\
(\mathrm{n}=39) ; \\
\text { Malawi }(\mathrm{n}=34)\end{array}$ & 43 & $2418(86.05)$ & $\begin{array}{l}\text { USA }(n=961) \\
\text { UK }(n=566) ; \\
\text { Switzerland } \\
(n=133)\end{array}$ \\
\hline Uganda & 896 & 15 & $133(14.84)$ & $\begin{array}{l}\text { South Africa } \\
(\mathrm{n}=49) ; \\
\text { Zimbabwe } \\
(\mathrm{n}=18) ; \\
\text { Tanzania } \\
(\mathrm{n}=16)\end{array}$ & 27 & $763(85.16)$ & $\begin{array}{l}\text { USA }(n=309) ; \\
\text { UK }(n=175) ; \\
\text { Canada } \\
(n=40)\end{array}$ \\
\hline Kenya & 537 & 14 & $94(17.50)$ & $\begin{array}{l}\text { South Africa } \\
(\mathrm{n}=41) ; \\
\text { Uganda } \\
(\mathrm{n}=13) ; \\
\text { Zambia }(\mathrm{n}=7)\end{array}$ & 19 & $443(82.50)$ & $\begin{array}{l}\text { USA }(\mathrm{n}=227) ; \\
\text { UK }(\mathrm{n}=77) ; \\
\text { Canada \& } \\
\text { Netherlands } \\
(\mathrm{n}=37)\end{array}$ \\
\hline Malawi & 387 & 14 & $65(16.80)$ & $\begin{array}{l}\text { South Africa } \\
(\mathrm{n}=29) ; \\
\text { Zimbabwe } \\
(\mathrm{n}=9) ; \text { Uganda } \\
(\mathrm{n}=5)\end{array}$ & 20 & $322(83.20)$ & $\begin{array}{l}\text { UK }(n=106) ; \\
\text { USA }(n=101) ; \\
\text { Canada } \\
(n=29)\end{array}$ \\
\hline Tanzania & 324 & 13 & $53(16.36)$ & $\begin{array}{l}\text { South Africa } \\
(\mathrm{n}=15) ; \\
\text { Uganda } \\
(\mathrm{n}=11) ; \text { Kenya } \\
\& \text { Zambia } \\
(\mathrm{n}=5)\end{array}$ & 21 & $271(83.64)$ & $\begin{array}{l}\text { USA }(n=93) ; \\
\text { UK }(n=49) ; \\
\text { Sweden } \\
(n=35)\end{array}$ \\
\hline Zimbabwe & 216 & 12 & $54(25)$ & $\begin{array}{l}\text { South Africa } \\
(\mathrm{n}=31) ; \\
\text { Malawi }(\mathrm{n}=7) ; \\
\text { Uganda }(\mathrm{n}=5)\end{array}$ & 18 & $162(75)$ & $\begin{array}{l}\text { UK }(n=56) ; \\
\text { USA }(n=49) ; \\
\text { Norway } \\
(n=19)\end{array}$ \\
\hline Zambia & 257 & 14 & $52(20.23)$ & $\begin{array}{l}\text { South Africa } \\
(\mathrm{n}=21) ; \\
\text { Zimbabwe } \\
(\mathrm{n}=7) ; \text { Uganda } \\
(\mathrm{n}=6)\end{array}$ & 20 & 205 (79.77) & $\begin{array}{l}\text { USA }(n=85) \\
\text { UK }(n=53) ; \\
\text { Switzerland } \\
(n=14)\end{array}$ \\
\hline Nigeria & 190 & 10 & $32(16.84)$ & $\begin{array}{l}\text { South Africa } \\
(n=17) ; \text { Ghana } \\
(n=4) ; \text { Kenya. } \\
\text { Saudi Arabia } \\
\text { \& Uganda } \\
(n=2)\end{array}$ & 20 & 158 (83.16) & $\begin{array}{l}\text { USA }(n=89) \\
\text { UK }(n=29) ; \\
\text { Germany } \\
(n=6)\end{array}$ \\
\hline Ethiopia & 194 & 9 & 29 (14.95) & $\begin{array}{l}\text { South Africa } \\
(\mathrm{n}=17) ; \\
\text { Uganda }(\mathrm{n}=3) ; \\
(\text { Sudan \& } \\
\text { Kenya } \mathrm{n}=2)\end{array}$ & 21 & 165 (85.05) & $\begin{array}{l}\text { USA }(n=34) ; \\
\text { Belgium } \\
(n=31) ; U K \\
(n=18)\end{array}$ \\
\hline Cameroon & 166 & 12 & $42(25.30)$ & $\begin{array}{l}\text { South Africa } \\
(\mathrm{n}=21) ; \\
\text { Burkina Faso }\end{array}$ & 14 & $124(74.70)$ & $\begin{array}{l}\text { France } \\
(\mathrm{n}=43) ; \mathrm{USA}\end{array}$ \\
\hline
\end{tabular}


$(\mathrm{n}=4)$; (Côte

( $\mathrm{n}=33)$; Italy

d'Ivoire \&

$(\mathrm{n}=13)$

Madagascar

$\mathrm{n}=3$ )

\begin{tabular}{|c|c|c|c|c|c|c|c|}
\hline \multicolumn{2}{|c|}{$\begin{array}{l}\text { Non-leadership } \\
\text { collaboration }\end{array}$} & \multicolumn{3}{|c|}{ Collaborations with African countries } & \multicolumn{3}{|c|}{ Collaborations with non-African countries } \\
\hline Country & $\begin{array}{c}\text { Total } \\
\text { collaborations }\end{array}$ & $\begin{array}{c}\mathbf{N} \\
\text { countries }\end{array}$ & $\begin{array}{c}\mathbf{N} \\
\text { Collaborations } \\
(\%)\end{array}$ & $\begin{array}{l}\text { Main African } \\
\text { collaborators } \\
\text { (n } \\
\text { collaborations) }\end{array}$ & $\begin{array}{c}\mathbf{N} \\
\text { countries }\end{array}$ & $\begin{array}{c}\mathbf{N} \\
\text { Collaborations } \\
(\%)\end{array}$ & $\begin{array}{l}\text { Main non- } \\
\text { African } \\
\text { collaborators } \\
\text { (n } \\
\text { collaborations) }\end{array}$ \\
\hline $\begin{array}{l}\text { South } \\
\text { Africa }\end{array}$ & 2862 & 25 & $309(10.80)$ & $\begin{array}{l}\text { Uganda } \\
(\mathrm{n}=49) ; \text { Kenya } \\
(\mathrm{n}=41) ; \\
\text { Zimbabwe } \\
(\mathrm{n}=31)\end{array}$ & 37 & $2553(89.20)$ & $\begin{array}{l}\text { USA }(n=1418) ; \\
\text { UK ( } n=439) ; \\
\text { Switzerland } \\
(n=134)\end{array}$ \\
\hline Uganda & 1248 & 16 & $96(7.69)$ & $\begin{array}{l}\text { South Africa } \\
(\mathrm{n}=39) ; \text { Kenya } \\
(\mathrm{n}=13) ; \\
\text { Tanzania } \\
(\mathrm{n}=11)\end{array}$ & 21 & $1152(92.31)$ & $\begin{array}{l}\text { USA }(n=741) \\
\text { UK }(n=176) ; \\
\text { Canada } \\
(n=69)\end{array}$ \\
\hline Kenya & 1194 & 19 & $80(6.70)$ & $\begin{array}{l}\begin{array}{l}\text { South Africa } \\
(\mathrm{n}=27) ; \\
\text { Uganda } \\
(\mathrm{n}=16) ; \\
\text { Botswana \& } \\
\text { Tanzania } \\
(\mathrm{n}=5)\end{array}\end{array}$ & 22 & $1114(93.30)$ & $\begin{array}{l}\text { USA }(n=789) ; \\
\text { UK }(n=95) ; \\
\text { Canada } \\
(n=83)\end{array}$ \\
\hline Malawi & 652 & 12 & 65 (9.97) & $\begin{array}{l}\begin{array}{l}\text { South Africa } \\
(\mathrm{n}=34) ;\end{array} \\
\text { Uganda }(\mathrm{n}=8) ; \\
\text { Zimbabwe } \\
(\mathrm{n}=7)\end{array}$ & 21 & $587(90.03)$ & $\begin{array}{l}\text { USA }(n=328) ; \\
\text { UK }(n=122) ; \\
\text { Italy }(n=34)\end{array}$ \\
\hline Tanzania & 643 & 9 & $53(8.24)$ & $\begin{array}{l}\text { South Africa } \\
(\mathrm{n}=19) ; \\
\text { Uganda } \\
(\mathrm{n}=16) ; \\
\text { Botswana } \\
(\mathrm{n}=6)\end{array}$ & 18 & $590(91.76)$ & $\begin{array}{l}\text { USA }(n=335) \\
\text { UK }(n=95) ; \\
\text { Denmark } \\
(n=26)\end{array}$ \\
\hline Zimbabwe & 538 & 9 & $88(16.36)$ & $\begin{array}{l}\text { South Africa } \\
(\mathrm{n}=44) ; \\
\text { Uganda } \\
(\mathrm{n}=18) ; \\
\text { Malawi }(\mathrm{n}=9)\end{array}$ & 20 & $450(83.64)$ & $\begin{array}{l}\text { USA }(n=216) ; \\
\text { UK }(n=156) ; \\
\text { Netherlands \& } \\
\text { Switzerland } \\
(n=17)\end{array}$ \\
\hline Zambia & 544 & 12 & $66(12.13)$ & $\begin{array}{l}\text { South Africa } \\
(\mathrm{n}=28) ; \text { Kenya } \\
(\mathrm{n}=7) ; \text { Uganda } \\
(\mathrm{n}=6)\end{array}$ & 19 & $478(87.87)$ & $\begin{array}{l}\text { USA }(n=297) ; \\
\text { UK }(n=77) ; \\
\text { Switzerland } \\
(n=27)\end{array}$ \\
\hline Nigeria & 281 & 12 & $50(17.79)$ & $\begin{array}{l}\begin{array}{l}\text { South Africa } \\
(n=27) ;\end{array} \\
\text { Uganda }(n=6) ; \\
\text { Ghana \& } \\
\text { Kenya }(n=3)\end{array}$ & 14 & $231(82.21)$ & $\begin{array}{l}\text { USA }(n=155) ; \\
\text { UK }(n=27) ; \\
\text { Netherlands } \\
(n=17)\end{array}$ \\
\hline Ethiopia & 200 & 8 & $20(10)$ & $\begin{array}{l}\text { South Africa } \\
(\mathrm{n}=7)\end{array}$ & 15 & $180(90)$ & $\begin{array}{l}\text { USA }(n=65) ; \\
\text { Sweden } \\
(n=40) ;\end{array}$ \\
\hline
\end{tabular}


Botswana \&

Kenya $(\mathrm{n}=3)$

Cameroon
10

37 (14.68)
South Africa

$(\mathrm{n}=22)$;

Burkina Faso

\& Gabon

$(\mathrm{n}=3)$
Netherlands

$(n=18)$

15215 (85.32) France

$(\mathrm{n}=88) ; \mathrm{USA}$

$(\mathrm{n}=73)$;

Germany

$(n=13)$

Table 4. HIV/AIDS research papers by Web of Science categories, according to African involvement, $2010-2017$

\begin{tabular}{|c|c|c|c|c|c|c|}
\hline \multirow[t]{2}{*}{ WoS Category } & \multicolumn{2}{|c|}{$\begin{array}{l}\text { Global } \\
\text { research }\end{array}$} & \multicolumn{2}{|c|}{$\begin{array}{c}\text { Solely African } \\
\text { research }\end{array}$} & \multicolumn{2}{|c|}{$\begin{array}{l}\text { African+global } \\
\text { collaborations }\end{array}$} \\
\hline & $\mathbf{N}$ & $\%$ & $\mathbf{N}$ & $\%$ & $\mathbf{N}$ & $\%$ \\
\hline Infectious Diseases & 20671 & 21.60 & 485 & 17.05 & 4471 & 37.37 \\
\hline Immunology & 15369 & 16.06 & 311 & 10.94 & 3290 & 27.50 \\
\hline $\begin{array}{l}\text { Public. Environmental \& Occupational } \\
\text { Health }\end{array}$ & 11853 & 12.38 & 742 & 26.09 & 2672 & 22.33 \\
\hline Virology & 10165 & 10.62 & 164 & 5.77 & 1417 & 11.84 \\
\hline Multidisciplinary Sciences & 5620 & 5.87 & 188 & 6.61 & 1467 & 12.26 \\
\hline Microbiology & 4989 & 5.21 & 60 & 2.11 & 824 & 6.89 \\
\hline Social Sciences. Biomedical & 4737 & 4.95 & 171 & 6.01 & 1023 & 8.55 \\
\hline Pharmacology \& Pharmacy & 4155 & 4.34 & 62 & 2.18 & 380 & 3.18 \\
\hline Medicine. General \& Internal & 3473 & 3.63 & 278 & 9.77 & 623 & 5.21 \\
\hline Health Policy \& Services & 2845 & 2.97 & 216 & 7.59 & 673 & 5.63 \\
\hline Respiratory System & 2657 & 2.78 & 168 & 5.91 & 752 & 6.29 \\
\hline Biochemistry \& Molecular Biology & 2582 & 2.70 & 50 & 1.76 & 88 & 0.74 \\
\hline Psychology. Multidisciplinary & 1973 & 2.06 & 87 & 3.06 & 439 & 3.67 \\
\hline Medicine. Research \& Experimental & 1872 & 1.96 & 41 & 1.44 & 204 & 1.71 \\
\hline Pediatrics & 1239 & 1.29 & 147 & 5.17 & 348 & 2.91 \\
\hline Health Care Sciences \& Services & 1207 & 1.26 & 98 & 3.45 & 311 & 2.60 \\
\hline Tropical Medicine & 1197 & 1.25 & 93 & 3.27 & 473 & 3.95 \\
\hline Biotechnology \& Applied Microbiology & 1075 & 1.12 & 40 & 1.41 & 111 & 0.93 \\
\hline Nursing & 918 & 0.96 & 44 & 1.55 & 102 & 0.85 \\
\hline Obstetrics \& Gynecology & 775 & 0.81 & 94 & 3.31 & 197 & 1.65 \\
\hline
\end{tabular}

Table 5. MeSH qualifiers of HIV/AIDS research papers, according to African involvement, 2010-2017 


\begin{tabular}{|c|c|c|c|c|c|c|}
\hline \multirow[t]{2}{*}{ Qualifier } & \multicolumn{2}{|c|}{ Global research } & \multicolumn{2}{|c|}{ Solely African research } & \multicolumn{2}{|c|}{ African+global collaborations } \\
\hline & $\mathbf{N}$ & $\%$ & $\mathbf{N}$ & $\%$ & $\mathbf{N}$ & $\%$ \\
\hline Epidemiology & 53,262 & 77.41 & 1220 & 42.90 & 5293 & 44.24 \\
\hline Immunology & 49,149 & 71.43 & 378 & 13.29 & 1805 & 15.09 \\
\hline Genetics & 38,248 & 55.59 & 264 & 9.28 & 1584 & 13.24 \\
\hline Metabolism & 33,536 & 48.74 & 174 & 6.12 & 668 & 5.58 \\
\hline Drug therapy & 30,764 & 44.71 & 978 & 34.39 & 4783 & 39.98 \\
\hline Therapeutic use & 29,749 & 43.23 & 681 & 23.95 & 3798 & 31.75 \\
\hline Virology & 28,082 & 40.81 & 462 & 16.24 & 2478 & 20.71 \\
\hline Complications & 25,058 & 36.42 & 728 & 25.60 & 2338 & 19.54 \\
\hline Psychology & 22,690 & 32.98 & 529 & 18.60 & 1930 & 16.13 \\
\hline Prevention \& control & 18,924 & 27.50 & 639 & 22.47 & 3212 & 26.85 \\
\hline Statistics \& numerical data & 18,496 & 26.88 & 498 & 17.51 & 2255 & 18.85 \\
\hline Diagnosis & 17,732 & 25.77 & 605 & 21.27 & 2362 & 19.74 \\
\hline Drug effects & 17,645 & 25.64 & 224 & 7.88 & 1106 & 9.24 \\
\hline Blood & 15,949 & 23.18 & 301 & 10.58 & 1262 & 10.55 \\
\hline Chemistry & 15,720 & 22.85 & 119 & 4.18 & 346 & 2.89 \\
\hline Administration \& dosage & 15,703 & 22.82 & 218 & 7.67 & 1461 & 12.21 \\
\hline Methods & 15,141 & 22.00 & 437 & 15.37 & 2223 & 18.58 \\
\hline Pharmacology & 14,377 & 20.89 & 135 & 4.75 & 739 & 6.18 \\
\hline Pathology & 11,124 & 16.17 & 186 & 6.54 & 654 & 5.47 \\
\hline Adverse effects & 11,122 & 16.16 & 213 & 7.49 & 798 & 6.67 \\
\hline Physiology & 10,677 & 15.52 & 106 & 3.73 & 511 & 4.27 \\
\hline Isolation \& purification & 8327 & 12.10 & 261 & 9.18 & 1310 & 10.95 \\
\hline Transmission & 8090 & 11.76 & 296 & 10.41 & 1546 & 12.92 \\
\hline Etiology & 6038 & 8.78 & 249 & 8.76 & 579 & 4.84 \\
\hline Economics & 5835 & 8.48 & 84 & 2.95 & 577 & 4.82 \\
\hline Therapy & 5416 & 7.87 & 196 & 6.89 & 525 & 4.39 \\
\hline Microbiology & 5377 & 7.81 & 181 & 6.36 & 718 & 6.00 \\
\hline Ethnology & 5007 & 7.28 & 66 & 2.32 & 237 & 1.98 \\
\hline Mortality & 4689 & 6.81 & 148 & 5.20 & 712 & 5.95 \\
\hline Pharmacokinetics & 4033 & 5.86 & 21 & 0.74 & 220 & 1.84 \\
\hline Physiopathology & 3912 & 5.69 & 89 & 3.13 & 255 & 2.13 \\
\hline
\end{tabular}

Table 6. MeSH terms of HIV/AIDS research papers 


\begin{tabular}{|c|c|c|c|c|c|c|}
\hline \multirow[t]{2}{*}{ MeSH Term } & \multicolumn{2}{|c|}{ Global research } & \multicolumn{2}{|c|}{ Solely African research } & \multicolumn{2}{|c|}{ African+global collaborations } \\
\hline & $\mathbf{N}$ & $\%$ & $\mathbf{N}$ & $\%$ & $\mathbf{N}$ & $\%$ \\
\hline HIV Infections & 55609 & 80.82 & 2431 & 85.48 & 10876 & 90.91 \\
\hline HIV-1 & 19945 & 28.99 & 378 & 13.29 & 2284 & 19.09 \\
\hline Anti-HIV Agents & 12114 & 17.61 & 434 & 15.26 & 2647 & 22.12 \\
\hline Risk Factors & 7494 & 10.89 & 390 & 13.71 & 1525 & 12.75 \\
\hline Viral Load & 6839 & 9.94 & 159 & 5.59 & 1290 & 10.78 \\
\hline Antiretroviral Therapy, Highly Active & 6758 & 9.82 & 327 & 11.50 & 1293 & 10.81 \\
\hline CD4 Lymphocyte Count & 6296 & 9.15 & 296 & 10.41 & 1604 & 13.41 \\
\hline Prevalence & 6172 & 8.97 & 463 & 16.28 & 1643 & 13.73 \\
\hline Treatment Outcome & 5074 & 7.37 & 200 & 7.03 & 1091 & 9.12 \\
\hline Sexual Behavior & 4636 & 6.74 & 179 & 6.29 & 949 & 7.93 \\
\hline Anti-Retroviral Agents & 4529 & 6.58 & 196 & 6.89 & 1266 & 10.58 \\
\hline Surveys and Questionnaires & 4137 & 6.01 & 313 & 11.01 & 859 & 7.18 \\
\hline Acquired Immunodeficiency Syndrome & 4047 & 5.88 & 253 & 8.90 & 524 & 4.38 \\
\hline Homosexuality, Male & 3986 & 5.79 & 22 & 0.77 & 239 & 2.00 \\
\hline HIV & 3802 & 5.53 & 138 & 4.85 & 537 & 4.49 \\
\hline Pregnancy & 3728 & 5.42 & 287 & 10.09 & 1557 & 13.01 \\
\hline HIV Seropositivity & 3604 & 5.24 & 241 & 8.47 & 787 & 6.58 \\
\hline RNA, Viral & 3497 & 5.08 & 48 & 1.69 & 467 & 3.90 \\
\hline Health Knowledge, Attitudes, Practice & 3468 & 5.04 & 268 & 9.42 & 761 & 6.36 \\
\hline Risk-Taking & 3418 & 4.97 & 90 & 3.16 & 505 & 4.22 \\
\hline United States & 3332 & 4.84 & 9 & 0.32 & 159 & 1.33 \\
\hline Coinfection & 3238 & 4.71 & 204 & 7.17 & 673 & 5.63 \\
\hline South Africa & 3197 & 4.65 & 832 & 29.25 & 2179 & 18.21 \\
\hline CD4-Positive T-Lymphocytes & 3186 & 4.63 & 63 & 2.22 & 356 & 2.98 \\
\hline Sexual Partners & 3042 & 4.42 & 103 & 3.62 & 725 & 6.06 \\
\hline Socioeconomic Factors & 2872 & 4.17 & 191 & 6.72 & 664 & 5.55 \\
\hline Incidence & 2758 & 4.01 & 113 & 3.97 & 723 & 6.04 \\
\hline Drug Resistance, Viral & 2750 & 4.00 & 42 & 1.48 & 500 & 4.18 \\
\hline Virus Replication & 2693 & 3.91 & 17 & 0.60 & 105 & 0.88 \\
\hline Time Factors & 2615 & 3.80 & 93 & 3.27 & 566 & 4.73 \\
\hline Genotype & 2577 & 3.75 & 64 & 2.25 & 473 & 3.95 \\
\hline
\end{tabular}

Figures 


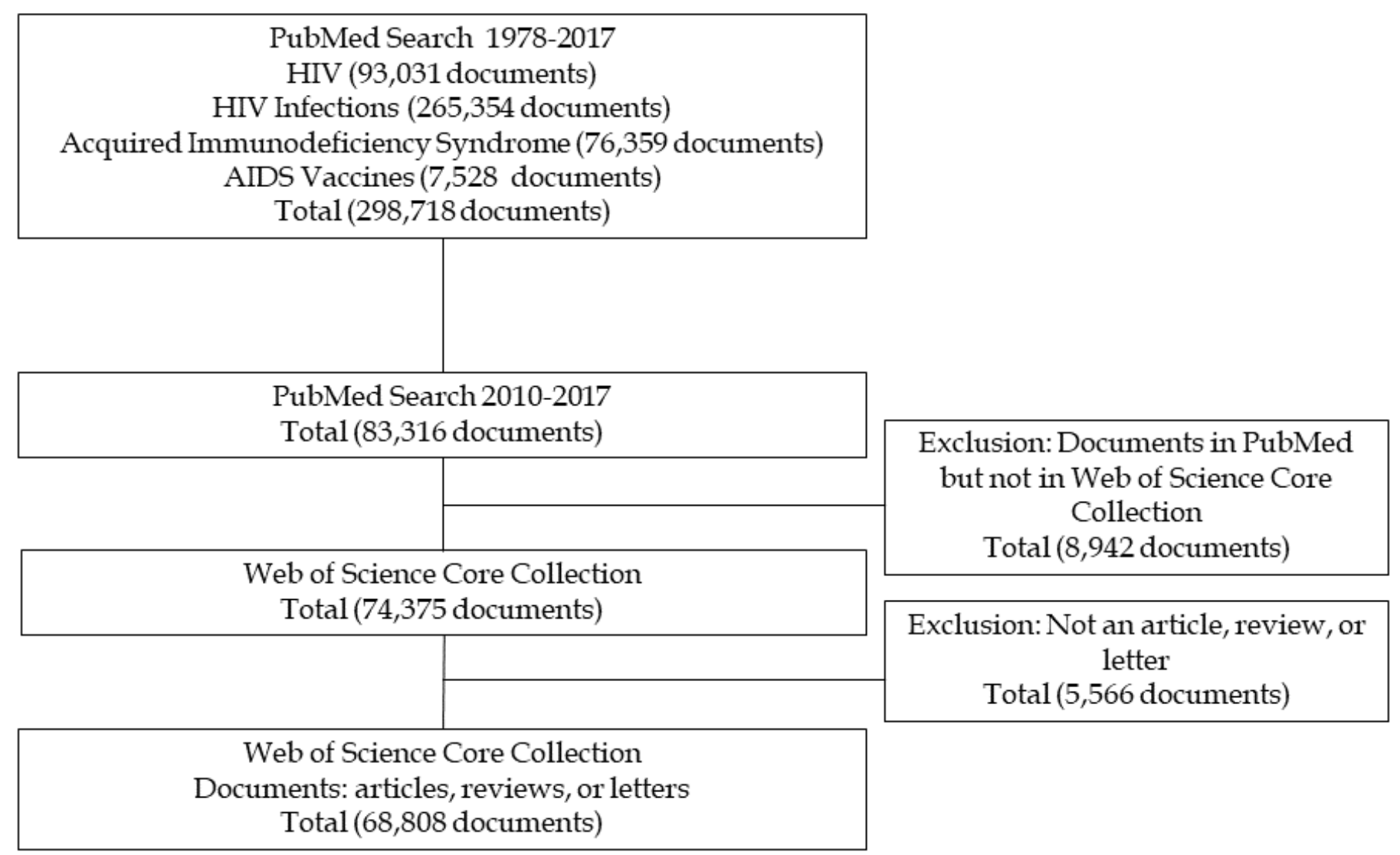

Figure 1

Flow chart for the selection of included documents 


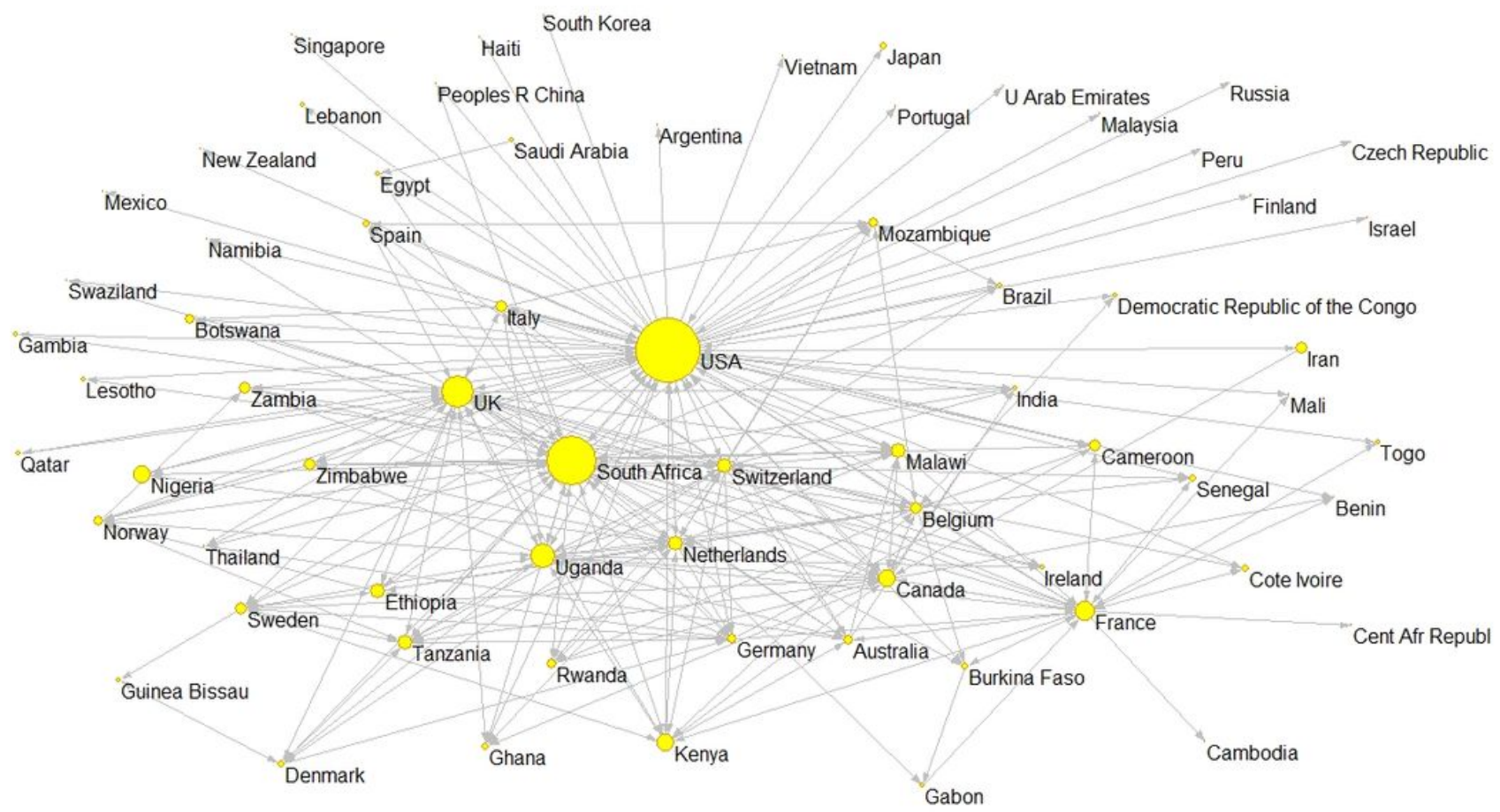

\section{Figure 2}

International collaboration network of research papers on HIV/AIDS with African and Middle Eastern countries (20102017)

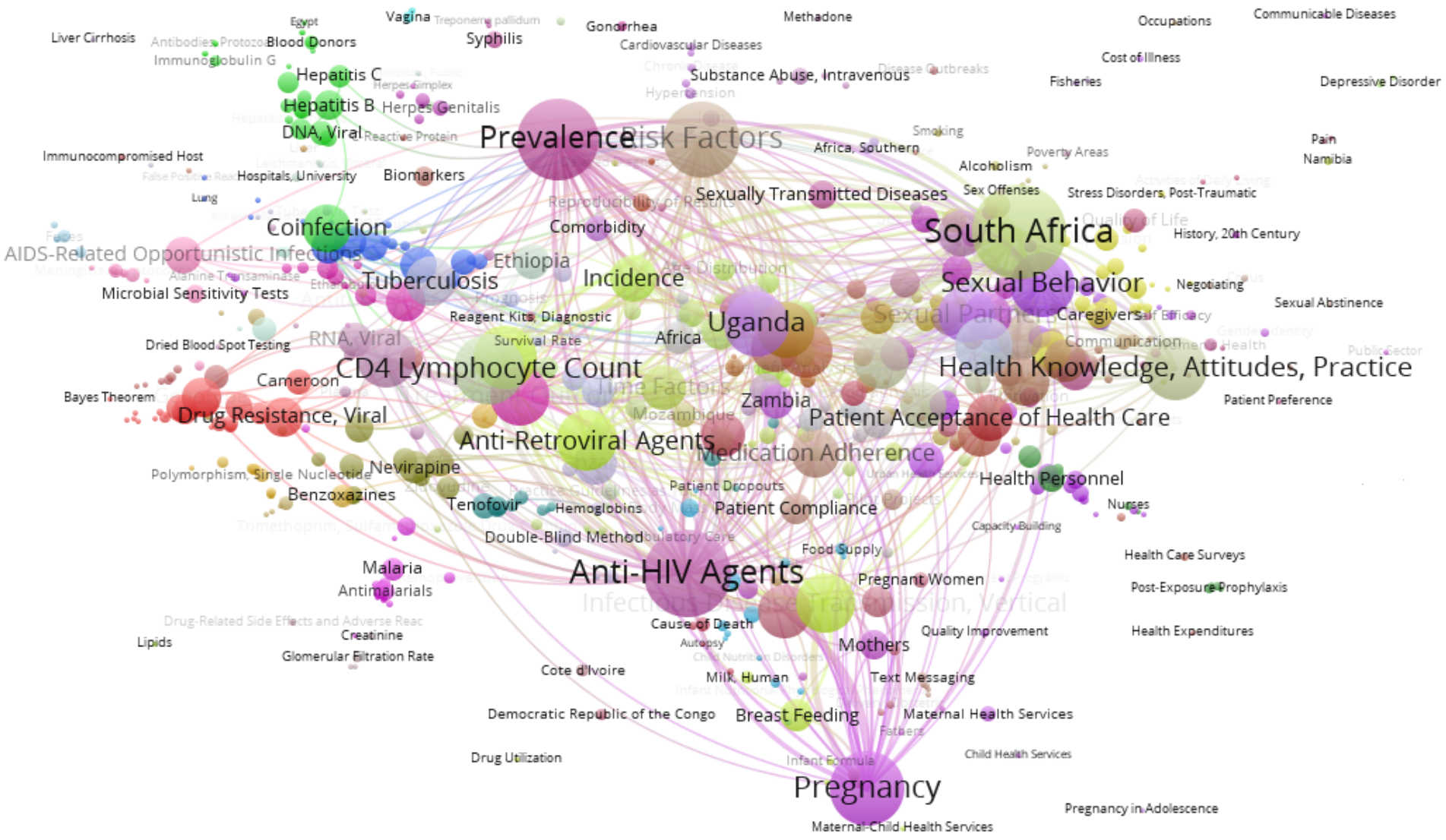

Figure 3 
MeSH co-occurrence network on HIV/AIDS research papers from African and Middle Eastern countries (2010-2017)

Page 25/25 